\title{
O SONHAR, O MAL SONHAR E O SONAMBULISMO NO HORIZONTE DA EXPERIENNCIA DO DESAPARECIMENTO FORCADO DE PESSOAS NO BRASIL
}

http://dx.doi.org/10.11606/issn.2237-1184.v0i23p212-229

\author{
Paulo Cesar Endo ${ }^{1}$
}

Universidade de São Paulo

\section{RESUMO}

O presente artigo discute alguns efeitos sociais, políticos e psíquicos do desaparecimento forçado como efeito de estratégias utilizadas no período da ditadura militar brasileira. Tais estratégias, que se escoravam e se escoram na certeza da impunidade e na indiferença diante das vítimas e dos sobreviventes, se presentificam hoje no agravo do sofrimento dos familiares ainda vivos, preservado pela letargia do Estado brasileiro, após o fim do período ditatorial, diante dos deveres em cumprir as principais resoluções internacionais de direitos humanos, relativas ao combate ao desaparecimento forçado de pessoas. Reconhecemos na elaboração onírica traços, pistas e pegadas de experiências que teimam em persistir e que ainda buscam seu estatuto linguageiro e seu reconhecimento social 50 anos após o golpe civil-militar no país. Este artigo apresenta resultado parcial de uma pesquisa longa e em curso, que pretende indicar matizes interpretativas diante das experiências do sonhar, da impossibilidade de sonhar, do sonambulismo e da vigília perpétua diante de experiências liminares.

\section{ABSTRACT}

This article discusses some social, political, and psychological effects of enforced disappearance as an effect of strategies used during the Brazilian military dictatorship. Such strategies are buttressed and anchor at the certainty of impunity and indifference to the victims and survivors. One of the main consequences of this indifference today is the aggravation of the suffering of family members still alive. It is preserved by the lethargy of the Brazilian state after the end of the dictatorship period, before the obligations to comply with the main international human rights resolutions relating to combating forced disappearance of persons. We recognize in the dream-work traces, tracks and footprints of experiences that still insist and seek their status of language and social recognition 50 years after the civilmilitary coup in Brazil. This article presents partial results of a long research which is intended to indicate interpretative nuances on the experience of dreaming, the impossibility of dreaming, sleepwalking and perpetual waking life before liminal experiences
PALAVRAS-CHAVE:

elaboração onírica.

ditadura.

desaparecimento forçado.

\section{PALAVRAS-CHAVE:}

dream-work. dictatorship. forced disappearance.

\footnotetext{
${ }^{1}$ Psicanalista e docente do Instituto de Psicologia e do Instituto de Estudos Avançados da Universidade de São Paulo.
} 


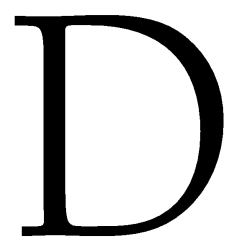

esde 1899, Freud ${ }^{2}$ postulou uma máxima para os sonhos e a elaboração onírica: os sonhos são a realização do desejo. Como formação psíquica singular os sonhos seriam o efeito da falta do objeto e, portanto, uma recriação fantasmática ante as pulsões eróticas que buscam imperativamente seu escoamento, mas que para isso dependem dos objetos aos quais se ligam. Trabalho do eu que funda, ao mesmo tempo, as negociações inexoráveis entre o psiquismo e a realidade e a experiência temporal que nos livra da tirania do instante e do imediato.

Essa dependência intransponível entre o imperativo do escoamento pulsional e os objetos, revela a própria natureza do psiquismo e um de seus princípios ordenadores: o princípio da realidade. A realidade é a experiência psíquica que indica que entre o vórtice das pulsões e o desejo há sempre um obstáculo a ser transposto e que a alienação psíquica, traço da neurose, diante desse obstáculo impõe espera e obliteração ao psiquismo e instaura sua condição de trabalho. Estado de suspensão entre a pulsão não resolvida ou não escoada - e o objeto impossível, situação frequentemente insolúvel dada a ver pelos sinais emitidos pelos sintomas.

A tensão provocada pela tensão intransponível da distância entre a pulsão e os objetos por ela visados, objetos impossíveis, subsistiria, no caso da neurose como formação conflitiva e sintomática e, portanto, como sofrimento psíquico.

Diante da ausência do objeto do desejo e do sofrimento imposto por essa frustração o psiquismo se põe ao trabalho para mitigar esse estado de penúria, criando oniricamente um objeto ausente (alucinatório): são os sonhos. O sonho seria um dos efeitos desse trabalho que realizaria, parcial e fantasmaticamente, o desejo insatisfeito. Trabalho realizado na calada da noite.

Em 1920, com o texto intitulado "Mais além do princípio do prazer", escrito por Freud imediatamente após a primeira guerra mundial e, consequentemente, com a miríade de experiências usurpadoras de todo

${ }^{2}$ FREUD, Sigmund. (1996). A interpretação de sonhos. In S. Freud, Edição standard brasileira das obras psicológicas completas de Sigmund Freud (Vols. 4-5). Rio de Janeiro: Imago. (Trabalho original publicado a pedido de Freud em somente em 1900, porém concluído em 1899). 
entendimento e compreensão vividas no contexto da guerra, Freud retorna aos sonhos.

Freud não conhecia a guerra e nunca foi em sua direção, mas a guerra, a primeira grande guerra, veio até ele ironicamente trazida, entre outras coisas, por alguns de seus discípulos diletos que lá estiveram convocados como médicos para atuarem em atividades, direta ou indiretamente, ligadas aos Estados em conflito.

Os rastros deixados pela guerra, pela experiência e reflexões de Karl Abraham, E. Simmel e Sandor Ferenczi, semeavam entre os psicanalistas freudianos e o próprio Freud, o desenvolvimento de uma clínica para o tratamento de neuróticos de guerra.

Dois momentos marcam essa influência: o $5^{\circ}$. congresso de psicanálise de Budapest em 1918, realizado nos estertores da primeira grande guerra e a publicação do livro Psicanálise e as neuroses de guerra em 1919 com textos de Ferenczi, Simmel, Abraham e Jones, com uma breve introdução de Freud. "Mais além do princípio do prazer", como é sabido, data de 1920.

Além disso, Freud teve dois de três de seus filhos e um de seus genros convocados para a guerra. É nesse contexto que Freud retoma suas pesquisas sobre os sonhos e dá passos adiante em sua promessa de pensar psicanaliticamente o trauma. ${ }^{3}$ O sintoma que o confunde: os sonhos traumáticos, sonhos de guerra. Expressões dramáticas que reproduzem a experiência catastrófica, lá onde o sujeito deveria encontrar guarida e apaziguamento: em seu sono. Os sonhos traumáticos agitam o psiquismo, a ponto de exigirem uma resposta somática, não raro acompanhada de sudorese, taquicardia, agitação e que culmina com o despertar. O sujeito é lançado para fora do seu sono, atormentado pelo sonho que o impediu de dormir.

A função mister do sonho - a de preservar o sono - entrara em colapso e, em seu lugar, a exigência da experiência vigil indicando que, para aquele que corre perigo, o sono tranquilo é proibido. A natureza desse perigo, entretanto, revelara seu inequívoco caráter somático, e não apenas psíquico, exigindo uma resposta igualmente física e motora - o despertar, a sudorese, a taquicardia - evidenciando que tal experiência não pode mais ser contida no âmbito da experiência psíquica por excelência - no sonho -, mas vaza para o corpo indicando um tormento excessivo impossível de ser contido como experiência psíquica.

\footnotetext{
${ }^{3}$ Há diversos momentos na obra freudiana, em que Freud indica essa dívida e essa insuficiência da psicanálise para pensar o trauma provocado por um agente externo analogamente ao trauma físico, mas diferente dele. Remeto o leitor para ENDO, Paulo Cesar.(2005) A Violência no Coração da Cidade: Um Estudo Psicanalítico. São Paulo: Escuta, especialmente ao capítulo A violência no pensamento de Freud, onde investigo isso demoradamente.
} 
Freud se volta então, em 1920, no texto "Mais além do princípio do prazer", para os sonhos novamente, mas dessa vez para atestar o fracasso da elaboração onírica que não pode mais ser reconhecida apenas como realização do desejo frustrado.

Nos sonhos traumáticos, ao que parece, é a literalização da experiência vivida e traumática que se compacta e se repete entre um corpo em dor e um psiquismo que, de certo modo, ignora esse sofrimento. Se não fosse assim, por que então o sonho, puro produto psíquico, reproduziria, literalmente, o sofrimento insuportável? Por que a ressurgência retraumatizante da experiência traumática, ela mesma reconstituiria o traumático e o repetiria infinitamente voltando a presentificar repetidamente, durante o sonho, o terrível?

A experiência catastrófica reencontraria então um acesso privilegiado à experiência psíquica, revelando a mesma força e impacto presentes no instante de gênese do traumático, na ocasião da experiência traumática. Tudo se passa como se uma das características do traumático consistisse na restituição psíquica da experiência catastrófica, não mais presente, porém refeita e presentificada como trauma, no sonho traumático que a repete e insiste na repetição do insuportável. Cito trecho de outro artigo meu que discute a elaboração onírica na literatura de testemunho no Brasil pósditadura:

\begin{abstract}
Assim um elemento novo tornava-se visível para Freud: a sobrevivência no psiquismo de um sofrimento psiquicamente insuportável, fisicamente insistente, mas que encontrava um índice de permanência na experiência produzindo, a posteriori, o instante sempiterno, infinitamente revisitado pelos soldados que estiveram na guerra e ali viveram o horror, para depois voltar a vivê-lo em seus sonhos. $^{4}$
\end{abstract}

A formação do trauma, no entanto, não consiste apenas na restituição literal de um sofrimento passado, mas numa formação atravessada por particularidades do sujeito que adensam e complexificam o sentido dos sonhos traumáticos e o trauma.

O medo ocasional da morte diante de uma situação perigosa encontraria uma sedimentação no trauma que os sonhos traumáticos revelam. O medo da morte, a presença física e compacta da morte, reluta em desaparecer e permanece, frequentemente, como herança alucinatória da situação catastrófica.

\footnotetext{
${ }^{4}$ ENDO, Paulo Cesar.(2012a) Elaboração onírica, sonhos traumáticos e representação na literatura de testemunho pós-ditadura no Brasil. In: SELigMANN-SilvA, Marcio, Ginzburg,J.Foot Hardman,F.(orgs). "Escritas da violência". vol. II, pp.119132:"Representação da violência na história e na cultura contemporâneas". Rio de Janeiro: 7 letras, p.122
} 
Barbara Engelking, psicóloga e pesquisadora polonesa da universidade de Varsóvia, em seu livro intitulado Memory and Holocaust (p.246) destaca a permanência nos sobreviventes dos traços da iminente possibilidade da morte. ${ }^{5}$ Esses traços são associados às experiências passadas, nas quais o risco de perder a vida era constante. Nesses casos, alienar-se da possibilidade da morte, como fazemos em nossa vida cotidiana, torna-se muito difícil e raro após experiências traumáticas duradouras que exigem atenção diuturna.

Esses traços permanentes de percepção de uma situação de perigo, e o medo que os acompanham, podem ser compreendidos a partir da experiência do tempo que escoa rapidamente diante da tarefa e da urgência em preservar a vida. A vida em risco e o tempo que resta, vivido como insuficiente para manter-se vivo, podem perdurar como uma luta pessoal contra a passagem do tempo. O tempo inexorável de uma destruição por vir e a iminência de uma força que se opõe às defesas psíquicas dramatizadas literalmente no sonho traumático.

O que funda o traumático, não raro, é a urgência da tarefa de manter-se vivo diante de forças que impõem (e desejam) o aniquilamento do sujeito. Aniquilamento que está longe de se esgotar na ameaça física da morte. Porque frequentemente, tal como inúmeros testemunhos e os relatos de sonhos nos ensinam, é antes negação da singularidade a partir da exibição vexatória, da nudez imperativa ou da simples ausência da experiência privada e secreta que definem as condições da experiência traumática. Retomo brevemente uma observação de minha amiga Flávia Schilling, relatando sua saída da prisão uruguaia após 7 anos:

(...) qual o maior problema da prisão? Exatamente o fato de que tua vida é pública, é vigiada, e quando você convive com 15, 16 pessoas o tempo todo numa cela, você obviamente não tem vida privada. Você tem privações de mil formas, mas sua vida é, de alguma maneira, sempre toda assistida. Então, quando saio da prisão, eu me preocupo exatamente por construir um anteparo, que achei muito saudável, de privacidade - de poder dançar, namorar, de poder ter uma vida absolutamente corriqueira e comum - e isso só é possível quando você não está sendo visto o tempo todo.

A tarefa de sobreviver, desse modo, é inextrincável da refundação das possibilidades de reconhecimento do outro como sujeito único, singularizado. O outro, para a psicanálise, é a realidade que se nos opõe e nos constitui. Essa realidade que se mostra diferida, estranha e por vezes irreconhecível até que se lance sobre ela o manto da familiaridade-provisória e

\footnotetext{
${ }^{5}$ ENGELKING, Barbara. (2001) Holocaust and Memory: the experience of holocaust ans its consequences: an investigation based on personal narratives. Trad: Emma Harris. London: Leicester University Press.(Trabalho original publicado em 1994), p.246 ${ }^{6}$ PERDIGÃO, Andréa Bomfim.(2005) Sobre o silêncio. São José dos Campos: Editora Parma ltda, p.154
} 
aconchegante - para depois se tornar ela mesma - a familiaridade- estranha e obtusa.

Diante da urgência de sobrevivência psíquica, reconhecida também como dever de proteger a integridade física, não raro persevera a percepção de que, de um lado essa proteção não pode mais ser adiada e nem esquecida e tem de ser antecipada, vigiada; de outro vige a sensação inexorável de que não é possível atender a urgência exigida e por detrás dessa impossibilidade surge o terror da morte iminente.

Trata-se de uma luta de preservação de um tempo vivido a ser preservado das urgências, do imediato e da iminência de ameaças e ataques à própria experiência temporal, que empurram o sujeito de encontro à ausência de toda e qualquer mediação diante da ameaça da aniquilação e da morte. Elaine Scarry já disse que um dos objetos privilegiados da tortura é o ataque à experiência temporal a partir do controle do espaço.

Portanto, torna-se imperativo permanecer vigil e alerta para evitar que a vida não seja, uma vez mais, colocada em risco. O sonho revela essa necessidade, pois para aquele que está sob risco de vida o sono tranquilo não é mais possível. O sonho traumático é o porta-voz dessa intranquilidade e da impossibilidade do sono pacífico.

A dor psíquica que se revela como experiência do sonho é, portanto, a do terror da morte diante da vida frágil e em risco perante a morte que advém. É a experiência do futuro como perigo que, não raro, pode por fim à esperança. A atenção se concentra naquilo que virá do passado e que condenará o futuro a não ser mais do que a expectativa da repetição do passado atroz.

Os sonhos traumáticos revelariam então essa perturbação de sua tarefa psíquica, tanto do ponto de vista de sua função (impedir o sono e o descanso e permanecer refém de um perigo no porvir), quanto do ponto de vista de seu conteúdo (a suspeita da catástrofe vindoura, a sensação de que algo terrível está para acontecer e de que nada, nem ninguém, serão capazes de impedir que intensidades de proporções terroríficas e surpreendentes se imponham).

Esse tempo, indicado pelo domínio da experiência catastrófica que se apresenta no sonho traumático, é um tempo que justapõe e rompe cronologias - propriedade do sonho, mas também revela uma impossibilidade de seguir adiante no tempo e no espaço do próprio sonho.

\footnotetext{
${ }^{7}$ SCARRY, Elaine. (1985) The body in pain: the making and unmaking of the world. New York: Oxford University Press.
} 
Foi Charlotte Beradt ${ }^{8}$, em seu livro raro e profuso e em sua proposição simples e absolutamente original, quem indicou possibilidades até então inéditas para o pensamento e a investigação sobre os sonhos.

Entre 1933 e 1939, desde a ascensão de Hitler ao poder na Alemanha como chanceler alemão, e 1939, ano do início da segunda grande guerra Charlotte Beradt recolhe cerca de 300 sonhos de cidadãos alemães comuns. Esses sonhos serão publicados na Alemanha apenas em 1966. Foi o primeiro livro de Charlotte Beradt, então com 65 anos e intitulado The Third Reich of Dreams.

Esse livro é uma peça rara, um acervo com vida própria, escrito por obra de uma compreensão muito sutil e rara dos acontecimentos políticos, sociais e psíquicos que antecederam a segunda guerra mundial. Por isso mesmo inesgotável nas possibilidades que suporta e sugere.

Seu principio era recolher essas narrativas de sonho como um meio de oposição ao nacional socialismo. Diz Beradt (2004): "Isso que eu fiz, eu o fiz como oposição política e não como judia designada como tal."

E ainda:

O terror marrom e a política vermelha foram os eventos determinantes que marcaram minha vida. Por isso depois dos sonhos eu publiquei uma biografia do homem político Paul Levi que foi o primeiro dirigente do partido comunista a partir de 1921, se revoltou contra a ditadura da Rússia e foi, consequentemente vítima do primeiro expurgo do partido comunista (alemão), ele e seus apoiadores. ${ }^{10}$

Nenhuma dúvida sobre o endereçamento claro e consciente de seu trabalho, portanto. Mas é provavelmente por isso que não só esse empreendimento quanto os atravessamentos e endereçamentos que essa obra permite, são hoje tão fundamentais. Ela viu no trabalho, na narrativa e na experiência do sonho não apenas restos, resquícios e sinais, mas a evidência flagrante dos entalhes de uma estratégia de dominação que se inscreve como um gotejamento insistente, contínuo e ininterrupto na vida cotidiana (everyday life) de pessoas comuns.

Não se trata, portanto, de sonhos aturdidos e acompanhados pela execução física, pela eliminação iminente da realidade dos campos de concentração e extermínio, mas de sonhos que devem seu caráter premonitório a suspeita que toda violência inscreve no psiquismo onde um combate invisível se trava. Como no comentário 'premonitório' de Freud a

\footnotetext{
${ }^{8}$ BERADT, Charlotte.(2004). Revêr sous Le IIIe. Reich. Trad. Pierre Saint-German. Paris. (trabalho original publicado em 1966). ${ }^{9}$ BERADT, Charlotte.(2004). Revêr sous Le IIIe. Reich. Trad. Pierre Saint-German. Paris. (trabalho original publicado em 1966), p. 8

${ }^{0}$ BERADT, Charlotte. (2004). Revêr sous Le IIIe. Reich. Trad: Pierre Saint-German. Paris. (trabalho original publicado em 1966), p. 8
}

218| D O S S I Ê : LITERATURA E MEMÓRIA 
Ernest Jones após saber que seus livros haviam sido queimados em 1933, juntamente com os livros de Albert Einstein e Karl Marx e outros pensadores judeus, por ordem de Hitler. Teria dito Freud: "que progressos estamos fazendo, na idade média teriam queimado a mim, hoje se contentam em queimar meus livros"11. Que literalidade premonitória impressionante se superpõe a essa ironia que Freud faz nesse comentário, ainda ignorante dos crematórios que serão prática do estado nacional socialista alemão após 1942, e para onde foram deportadas suas 4 irmãs: Marie, Pauline e Rosa deportadas para Treblinka e Adolphine para Therezin. Como sabemos Marie, Pauline e Rosa foram assassinadas nas câmaras de gás e incineradas nos crematórios e Adolphine morreu doente em Therezin.

Esse é o sentido premonitório dos sonhos. Não porque eles antecipam o ainda não acontecido do tempo futuro, mas porque eles aprofundam a um ponto que vaza a compreensão consciente, informada e deliberada que temos de nossa inscrição no tempo histórico presente.

Beradt se interessou pelos efeitos profundos, somente visíveis nos sonhos, que conduzem a experiência de viver sob a ameaça dos regimes totalitários. Um paroxismo ao mesmo tempo fantástico e inimaginável, porém plenamente exequível no contexto das práticas empreendidas nos regimes de exceção.

Isso que adquire um aspecto ridículo e grostesco no nazismo ${ }^{12}$ e que levou Victor Klemperer a comparar os discursos de Hitler aos 'espetáculos da ópera Kroll' ou suas manifestações públicas como números de carnaval, revela um efeito profundamente contraditório e absurdo que só o sonho pode capturar. O terrorífico, porém, é que diante disso "os alemães não estão rindo, eles estão aplaudindo essas gesticulações e essas manifestações"13 (Beradt, 2004, p.40). Esse apoio ao grotesco será exacerbado, como sabemos, ao ponto do surreal e do catastrófico.

O sonho recolherá o absurdo no qual o grotesco da condensação se torna sua verdade e o ridículo do deslocamento revela, no sonho, sua inquietante estranheza. Uma experiência de descrença acompanha o sonho, para revelar uma verdade muito difícil de ser explicada. No máximo ela será narrada pelo sonhador que, a princípio, ignora sua autoria e o caráter singular do próprio sonho que o trabalho psicanalítico permite repor.

\footnotetext{
${ }^{11}$ GAY, Peter. (1989). Uma vida para nosso tempo. Trad: Denise Bottman. São Paulo: Companhia das letras.(trabalho original publicado em 1988), p.536

${ }^{12}$ BERADT, Charlotte.(2004). Revêr sous Le IIIe. Reich. Trad. Pierre Saint-German. Paris. (trabalho original publicado em 1966), p. 40

${ }^{3}$ BERADT, Charlotte.(2004). Revêr sous Le IIIe. Reich. Trad. Pierre Saint-German. Paris. (trabalho original publicado em 1966), p. 40
}

219| D O S S I Ê : LITERATURA E MEMÓRIA 
Ao compilar 300 sonhos de cidadãos comuns entre 1933-1939 na Alemanha nazista, Charlotte Beradt indica que há um trabalho psíquico em curso diante dos mecanismos de captura totalitários. Esse trabalho pode prever um risco de sofrimento por vir a partir dos indícios de dominação do sujeito, do ataque e captura de sua singularidade pelos estados totalitários e pelas ditaduras, cujos indícios o psiquismo extrai da vida desperta cotidiana e não, como no trauma, da irrupção e da intensidade da experiência já vivida em outro tempo e lugar.

Cito Beradt (2004) em seu comentário sobre os sonhos vividos durante o Terceiro Reich:

(...) mas os sonhos desse gênero, os jornais da noite por assim dizer, parecem registrar minuciosamente, como sismógrafos, o efeito de eventos políticos exteriores no interior dos homens, resultado de uma atividade psíquica involuntária. As imagens do sonho poderiam assim ajudar a compreender a estrutura de uma realidade no ponto de sua transformação em pesadelo. ${ }^{.14}$

Essa 'premonição' à catástrofe política e social revelaria que, no sonho, algo se antecipa porque se aprofunda e trabalha para compreender e evitar o pior, mas também que a devida compreensão da história supõe um acesso à inscrição própria do sujeito no tempo histórico que pode nos ser dada pelo sonho. Isso que Freud havia destacado como uma das funções do eu antecipar-se diante do perigo e, assim possibilitar que haja um futuro - está presente nos sonhos sob o $3^{\circ}$. Reich, como demonstra Beradt.

Cito um dos sonhos compilados por Beradt ${ }^{15}$ :

Goebbels vem à minha usina. Ele exige que as pessoas fiquem à direita e à esquerda. Eu devo me colocar ao meio e elevar o braço para fazer a saudação Hitleriana. É preciso uma meia hora para eu conseguir elevar o braço, milímetro por milímetro. Goebbels observa meus esforços como se fosse um espetáculo, sem aplaudir, nem protestar. Mas quando eu enfim consigo estender o braço ele me diz essas cinco palavras: Sua saudação, eu a recuso. Dá meia volta e se dirige em direção à porta. Eu permaneço na minha usina, no meio do meu pessoal, em público, de braço elevado. É tudo o que posso fazer enquanto meus olhos fixam seu pé torto enquanto ele sai mancando. Até o meu despertar eu permaneço assim.

A humilhação do medo e da subserviência agravadas com a indiferença e o escárnio não poderiam ser mais profundamente experienciadas e descritas. A ambivalência ante a resistência em ceder e a impossibilidade de

\footnotetext{
${ }^{14}$ BERADT, Charlotte.(2004). Revêr sous Le IIIe. Reich. Trad. Pierre Saint-German. Paris. (trabalho original publicado em 1966), p. $50-51$

${ }^{5}$ BERADT, Charlotte.(2004). Revêr sous Le IIIe. Reich. Trad. Pierre Saint-German. Paris. (trabalho original publicado em 1966), p. 47
}

220| D O S S I Ê : LITERATURA E MEMÓRIA 
não ceder, não obedecer, não curvar-se encontram nessa formulação do sonho sua natureza solitária e o isolamento à que o sonhador se vê condenado. Sua submissão não lhe confere o agrado do inimigo que lhe dá as costas exibindo seu poder e sua claudicância, falha e imperfeição; ela lhe imobiliza no horror da derrota petrificada. A experiência extrema, e aterrorizante de ser humilhado por um manquitolante de farda, que lhe dá as costas diante da vexatória submissão.

Se o sonho revela um alijamento que impossibilita o consenso e se o compartilhamento é experiência fundamental que cria as possibilidades do consenso, é preciso também considerar que muitas das experiências totalitárias, ao atacarem a possibilidade da singularização e da apropriação, no fundo, ao atacar ativamente o sujeito, esvaziam ou mitigam as possibilidades do compartilhamento.

Sabemos que é o próprio psiquismo que é visado em muitas práticas de tortura. A danação do sujeito revela o bem sucedido da empreitada do torturador e da tortura. Porém, mesmo quando isso é aparentemente bem sucedido, quando a tortura levou o torturado até os portões da morte, do desespero e do silêncio uma centelha reaparece num escondido e pouco notado trabalho psíquico: nos sonhos.

Ainda que o assunto tenha se tornado proibido, constrangedor $e$ impossível de ser falado, a elaboração onírica restitui um sujeito guardado, que ainda vive profundamente o sentido das experiências de aniquilação inscritos subjetivamente. É como se os sonhos alertassem que lá longe ainda há experiências a descoberto que convocam a linguagem e o desejo de falar.

Muitas vezes o sonho e sua narrativa estranha é o que permite voltar a falar no assunto, até mesmo porque o sonho pode ser tomado distraidamente e sem grande relevância no mundo dos bem despertos. O sonho é a voz do que não calou, do que não desapareceu, do que não acabou e nem foi exterminado - já disse de muitas maneiras Sigmund Freud.

Nesse sentido discutirei brevemente uma ação específica e politicamente endereçada que expressa, de modo flagrante, a intenção do desaparecimento e a preservação do sofrimento como resistência a esse desaparecimento. Crime praticado extensamente no Brasil durante o período da ditadura militar, e que ainda persiste como prática comum cometida por agentes de estado no país. Trata-se dos desaparecimentos forçados. ${ }^{16}$

\footnotetext{
${ }^{16}$ A declaração sobre a proteção de todas as pessoas contra os desaparecimentos forçados adotada pela Assembleia Geral das Nações Unidas através da Resolução 47/133 de 18 de dezembro de 1992 define desaparecimento forçado como "detenção, prisão ou translado de pessoas contra a sua vontade, ou privação da liberdade dessas pessoas por alguma outra forma, praticada por agentes governamentais de qualquer setor ou nível, por grupos organizados ou por particulares atuando em nome do governo ou com seu apoio direto ou indireto, com sua autorização ou com seu consentimento, e que se neguem a revelar o destino ou o paradeiro dessas pessoas ou a reconhecer que elas estão privadas da liberdade, subtraindo-as, assim, da proteção da lei (...)" Disponível em: http:/www.dhnet.org.br/direitos/sip/onu/desaparec/lex71.htm. Data de acesso: 31/03/2014
} 
O desaparecimento forçado impõe para aqueles que ficam, uma experiência obtusa dificilmente ultrapassada. Revela-se como experiência ao mesmo tempo inconteste e absurda, porque produz uma fratura entre a inscrição da presença de um ente querido e sua desaparição inexplicável, jamais conferida consensualmente.

Além disso, o próprio processo de desaparecimento e a negação dele, pelos agentes que o provocaram, sugere uma irrealidade que não pode ser nem confirmada, nem aferida e constrange e induz a comunidade a negar, de algum modo, que aquele ente que se foi realmente existiu. Porque se o desaparecido se foi misteriosamente, sem traço ou pegadas e se, por outro lado, a autoria do sequestrador ou assassino jamais é revelada, a lógica induz que se não houve assassino ou sequestrador também é possível que não haja assassinado ou sequestrado.

O desaparecimento forçado se perpetua então enquanto enigma, suspenso entre duas irrealidades que jamais se coadunam ou conversam. A realidade da experiência daquele que teve seu amado desaparecido e jamais reencontrado, e a realidade da negação peremptória, institucional, governamental daqueles que teriam informações sobre o paradeiro e o destino do desaparecido e aos quais é permitido que as soneguem aos familiares, amigos e à coletividade e sociedade a qual o desaparecido pertencia e a qual o perpetrador deve explicações.

A experiência difícil que se elabora aí não se encontra forjada nas dinâmicas do esquecimento ou da lembrança, comuns às lutas pela memória política. Ou seja, nesse caso não se trata de lembrar, porque absolutamente nada pôde ser esquecido; como também não se trata de poder esquecer, realizar a morte do morto, porque é tão impossível matar o morto, que tanto se queria vivo, quanto dar a ele um destino histórico e celebratório digno de sua presença entre os que o prezavam, sem a constatação de sua morte comprovada.

Sendo assim o estranho destino do desaparecido forçado, angustiosamente preservado como invisível entre coisas e objetos visíveis, revela um estágio fronteiriço nutrido pela esperança e pela tristeza que não pôde e não pode cessar, porque não estar mais triste, superar a tristeza, seria realizar ou a vida ou a morte do desaparecido. Ambos impossíveis.

Quando um irmão de um desaparecido diz: "sempre quando escuto a porta se abrir, minha primeira expectativa é a de que seja ele entrando." Essa expectativa não dura, mas ela demarca uma tristeza mil vezes vivida e revivida. A vida triunfando sobre as expectativas de morte, para em seguida ser mais uma vez destruída. 
Ou quando o irmão de um desaparecido político relata que ${ }^{17}$ :

(...) lembro-me dos natais que eram sempre muito tristes, principalmente porque, por muitos anos nossa mãe não saia de casa na esperança dele voltar naquele dia, tinha medo de sair, de ele chegar e não encontrar ninguém e achar que havíamos mudado dali.

Há uma obrigação de tristeza que comprova que o desaparecido permanece vivo naqueles que o amam. A tristeza então, nesse caso, é o que dá testemunho de que o desaparecido ainda vive, de algum modo, em algum lugar. A tristeza é, de certo modo, a resistência à morte; a resistência ao desaparecimento sem paradeiro, sem responsabilização e sem sentido.

Apoiados nos pequenos gestos, nas lembranças íntimas, sutis e cotidianas aquele que vive a ausência do desaparecido protege e preserva o sentido contraditório que marca as lutas contras as atrocidades cometidas sob o manto da impunidade. Com isso, essas lutas reinventam e inscrevem na cultura uma tarefa difícil: a do dever de memória social que inclui a lembrança, não só das vítimas e sobreviventes ausentes, mas também a lembrança dos responsáveis pelos longos processos de sofrimento agravados pela indiferença e pela impunidade.

Trata-se de um zelo histórico que cuida e preserva o sentido que constitui o sujeito político e social e lhe confere um lugar que o faria, finalmente, reaparecer no contexto de sua ação política e de sua verdade subjetiva, precisamente desde o lugar do qual fora sacado e desaparecido.

Porém a busca pode também tornar-se aflitiva, incansável e atenta, uma busca que não cessa, nunca, em lugar algum. Como diz uma irmã:

Passei então a procurá-la, quando ia a restaurantes, a cinemas, a teatros. As vezes pensava ver minha irmã, corria atrás de alguém, para logo me decepcionar.

Situações que falam de uma montagem absurda que aquele que perdeu é obrigado a erguer para se manter nessa fronteira tênue entre a vida e a morte do desaparecido e, subjetivamente, sustentando ao mesmo tempo a própria vida e morte do ente que o perdeu.

Essa suspensão da realidade que não se confirma forja e delimita experiências subjetivas de suspeição e a impossibilidade de, após o desaparecimento, viver em paz. A luta ou a guerra que se trava tende a permanecer cada vez mais solitária e escusa.

\footnotetext{
${ }^{17}$ Os relatos a seguir foram dados por parentes de vítimas de desaparecimento forçado no Brasil no período em que vigeu a ditadura civil-militar no Brasil (1964-1985). Suas autorias e circunstâncias dos relatos estão sendo deliberadamente omitidas aqui, embora tais relatos sejam públicos.
} 
Mesmo que organizações de Direitos Humanos, sentenças em tribunais e companheiros confirmem o desaparecimento, nenhum deles pode confirmar a morte, o fim e, sendo assim, o estado de morto e vivo oscila num movimento pendular que exaure, se repete e constitui a experiência do absurdo de realidades justapostas. Realidades que perpetuamente se desencaixam, que não encontram interlocutor na vida em vigília e nem inteligibilidade lógica para aqueles cuja vida foi definitivamente atravessada pelo anonimato do desaparecimento forçado. Não há lugar social para o sofrimento inconsciente.

O dano e a força das ditaduras persiste, então, na preservação da miríade de coisas não esclarecidas, tabus que o estado não revela em sua eterna transição cínica e inacabada.

Permitir esse cinismo demorado é ratificar e proteger a herança das ditaduras que seguem protegidas em seu legado. Assassinados sem assassinos, torturados sem torturadores, estuprados sem estupradores são absurdos só compatíveis com a linguagem onírica que dispensa a lógica e tempo cronológico para reaver a gravidade e a extensão das formas e determinações inconscientes que regem o sujeito que sofre.

Só os sonhos figuram sem modéstia ou risco os surrealismos inventados em tempos de exceção e terror. A espera eterna pelo desaparecido obriga uma experiência fora do tempo, e ela também é torturante, como dizem alguns familiares.

A esperança e expectativa de que o desaparecido retorne, reapareça ou seja devolvido negocia com a afirmação material saudosa, compartilhada entre os vivos. Como destaca esse relato de uma irmã de desaparecido político:

Eu tinha 7 anos e lembro logo quando ele viajou, a mamãe colocava o almoço de todo mundo. Somos 8 filhos então ela que fazia o almoço de cada um. As meninas iam para a escola então quem fosse voltando voltava em hora diferente, então cada um almoçava na sua hora. E quando ele viajou eu sempre presenciava ela colocando o almoço e chorando. Ela colocava o almoço dele e guardava lá. Isso ficava o dia todo e depois eu nem sei o que ela fazia. Sempre eu ia e ficava olhando ela colocar o almoço.

(...)

A minha noção de tempo parece que foi muito tempo que ela fez isso, que ela chorava.

Pranto que não termina, não encontra termo, nem paradeiro e se escora e se transmite nos olhos do filho vivo, que também choram. 
O caráter durável dessas experiências, as exigências psíquicas excessivas que impõe e as consequências que produz na vida das pessoas dificilmente podem ser inteiramente compreendidas, mas podemos nos esforçar.

Há uma proximidade formal muito grande entre a maneira como o sonho se elabora e a maneira como tais experiências são vividas em vigília, no cotidiano e na vida que segue.

Como relata uma irmã: "...tinha muitos sonhos dele chegando e dizendo que estava aqui. Sabe aquela coisa de pronto, já normalizou e está aqui."

O sonho faz uso da reversibilidade temporal e põe termo à experiência sem fim do desaparecimento realizando o aparecimento. Pronto, acabou, ele apareceu. O momento de refúgio, regaço psíquico termina por ocorrer na experiência do sonhar já que o despertar marcará o reencontro com o irmão ainda desaparecido. Uma dor sem termo.

A experiência absurda do desaparecimento - nem vivo, nem morto; nem entre nós, nem em lugar algum adquire, no sonho, alguma plausibilidade e o sentido que ele refaz só o sonhador pode desvelar. Diz uma irmã:

Quando ele desapareceu começaram os boatos de que ele tinha morrido, eu tinha pelo menos nos primeiros 5 ou 6 anos, quase que toda semana o mesmo sonho. Era como se fosse um campo aberto, onde eu estava lá. Tinha uma mata de pelo menos $1 \mathrm{~km}$, mas na entrada da mata tinha uma pedra bem grande, e ele estava sentado nela. Do lado da pedra tinha uma caminho bem estreitinho entrando na mata, tipo uma trilha. Eu o olhava, o reconhecia e corria para encontrá-lo, sendo que ele se levantava, olhava para mim, entrava na trilha e desaparecia. Eu saía correndo atrás dele, mas quando eu chegava na beira da trilha, eu não podia entrar.

O enigma entre a pedra (a lápide?), tão desejada por um lado e o desejo de seguir o desaparecido, seja para onde for, revelam que lá onde ele está não pode ser seguido. Viver o desaparecimento torna-se, muitas vezes, para aqueles que ficaram, pior do que reconhecer a morte e o morto; pior que velar, enterrar e prantear seu morto; pior do que por termo a ausência. Desejo que compete e colide com o desejo de ver o desaparecido vivo, lépido, fora do alcance e a salvo.

Ainda nesse caso é possível imaginar um alívio concomitante. Algo como : Se fugiu de mim, se é inalcançável para mim não deve ter sido alcançado por ninguém.

A herança que resta é uma impossibilidade psíquica tal como no trauma, mas diferente dele. O que a experiência do desaparecimento forçado 
deixa, e os sonhos o demonstram, é a exigência do imobilismo psíquico que não pode, não deve e não é autorizado a iniciar o caminho de superação das coisas difíceis.

Qualquer possibilidade de superação psíquica dessa experiência exige a enunciação de um discurso que fale e seja compreendido pelo e para o sujeito e além dele. Compartilhado por muitos, inscrito como evidência especular reencontrada na história pessoal, familiar e social nas quais é possível se ver refletido como representação de si e refratado como representação sobre si.

A perenidade da tristeza que se exige social e psiquicamente, faz par com negligência política de Estados incapazes de ultrapassar a herança dos mecanismos de terror e morte, e o desprezo pelo futuro dos que perderam e perderão seus entes de modo violento e arbitrário e tem de conviver com isso como uma condenação perpétua.

Essa experiência de condenação se agrava no mesmo torvelinho onde a impunidade e a não responsabilização se perpetuam. O desaparecimento da vítima revela sua face social e institucionalmente autorizada: o concomitante desaparecimento também daquele que cometeu o desaparecimento, sequestro ou assassinato do desaparecido. Não aparecer com o desaparecido é, também, a garantia da impunidade dos perpetradores que ainda mantêm o desaparecido sob sua posse, única e exclusivamente para se proteger das consequências de sua ação deliberada. Mais ainda, são os torturadores e assassinos do passado que ainda retêm 'a verdade' sobre o ocorrido e, deliberadamente, a sonegam.

Aos que herdaram essa verdade incompleta e lacunar resta esperar que os perpetradores abram os arquivos, se disponham a depor e, finalmente, contribuam para a consolidação de uma verdade socialmente perene e consensual. São eles, os perpetradores, que no Brasil ainda patrimonializam a dor dos outros em seus calabouços perpétuos.

À dor, ao silêncio ou e à luta dos familiares de mortos e desaparecidos políticos no Brasil, se soma também uma tarefa empreendida há décadas: a de arrancar das mãos dos perpetradores as informações omitidas que poderiam dar paradeiro ao roteiro da memória, da celebração, do reconhecimento e do luto.

É uma tarefa capaz de restituir o que o sequestro temporal omite, esburacando pedaços inteiros da história pessoal, da comunidade, a quem os perpetradores devem respostas no momento em que se veem derrotados, envergonhados e entrincheirados em seus porões de impunidade. São eles que ainda celebram o culto à covardia, à omissão e à irresponsabilização que 
se reproduz como prática tolerada, deliberada e inconscientemente, e que atesta e define as relações entre os cidadãos e o Estado brasileiro pautadas no silenciamento e nos acordos na calada da noite.

A tristeza e a exaustão, nesse caso, revelam-se como impasse na busca por justiça numa situação em que o dolo é continuamente vivido e a punição perpetuamente adiada. A punição determinada pelo discurso e ação formal, jurídica, estatal confeririam à morte do morto o estado de pertencimento do qual foram isolados constituindo-se em carpideiras sem mortos para prantear.

A eterna busca pelos desaparecidos revelou uma das imagens cinematográficas mais potentes e oníricas sobre os períodos de exceção na América Latina e que emoldura e perfila o filme "Nostalgia da luz", de Patricio Guzman: parentes e amigos cavando no imenso deserto do Atacama, alienados de suas maravilhas e imersos em suas lembranças, esperanças e tristezas.

O cenário onírico do Atacama figura, de modo notável, as mulheres escavadoras de Calama entre os corpos soterrados no deserto e as estrelas que não existem mais, mas cuja luminosidade ainda brilha no firmamento. Metáfora potente que radicaliza o impasse entre a condenação melancólica e o direito à celebração; entre a terra seca e deserta e o céu mais limpo do mundo onde os telescópios mais potentes se instalam.

Passagem difícil e custosa para muitos que ainda buscam o direito de conspurcar seus entes queridos da determinação degenerada do desaparecimento ao privá-los de corpo, rosto e singularidade.

Nos sonhos essa tarefa ainda persiste e ela ainda repõe a possibilidade de velar os que se foram em lugares melhores do que aqueles onde foram largados. Nos sonhos um acontecimento inconcluso ainda preserva o desejo de narratividade e compartilhamento que principia quando o sonhador se anima a contar que, na noite passada, sonhou com seu desaparecido.

O sonho posto em imagens e a narrativa do sonho exibem esse aspecto fantástico que a literatura também requisita para si. O extraordinário do sonho seria dado por um desejo que não encontraria a possibilidade do objeto receptor e causa do desejo, inventando uma cenografia em que o desejo se reapresentaria como possível, no horizonte de seus objetos oníricos.

A imaginação confere ao sonho o peso da falta e o ônus dos restos e a narrativa o evoca para sua conversão em linguagem, provocando o sonho ao estabelecimento de ligações que a inteligibilidade narrativa lhe conferiria a posteriori.

Seria evocativo, no contexto desse trabalho, retomar brevemente o que na literatura revela o sonho do sonhador no horizonte ou na ausência do 
horizonte do traumático. O traumático pós-posto por suas deformações inimagináveis, imperecíveis nos cenários de horror permanentemente aprofundados nas situações de conflito, tensão e violência levou Mia Couto ${ }^{18}$ a elaborar, no contexto de uma Moçambique em guerra, um país sonâmbulo, uma terra que não dorme nem desperta, aturdida pela impossibilidade de repousar, pelo impossível descanso legado pelo trauma e movido adiante pelo traumático.

Na longa e perpétua deambulação ou sonanbulação de Tuahir, só haveria repouso na leitura, do livro de Kindzu, encontrado e conduzido em sua jornada pela terra devastada.

Lembremos que o sentido que Freud empresta aos sonhos traumáticos é, precisamente, o de um ataque ao estado do sono no qual se sonha. O sonho traumático recorre permanentemente à possibilidade do despertar, como se o sonho estivesse avesso ao descanso e infenso ao sono. O sonho como guardião do sonho seria como que convertido em seu contrário. Seria o sonho invadido e capturado pelo trauma, que atuaria como inimigo do descanso e da imobilidade psíquicas necessárias ao estado de repouso.

O sonho traumático engendraria o sonambulismo daquele que não quer acordar - não pode acordar - que o fantasma expresso no "nunca se deve despertar um sonâmbulo' conflagra. Porém que terrores estariam tentos naquele que não pode dormir - no sonâmbulo.

A terra tornada sonâmbula de Mia Couto seria a terra à qual foi retirada o direito ao repouso. Terra de mortos insepultos, de gritos ecoantes e sempiternos, de fantasmas demandantes e solitários e dos mortos que ainda se queria vivos.

Da terra sonâmbula, entretanto, seria preciso evocar a narrativa. Tensionar o possível e o impossível da linguagem até o ponto em que a língua velha se submenta às imagens novas e, mais uma vez, à interpretação. Trata-se da regressão tópica da qual falava Freud. Um retroagir da palavra à imagem ante o fracasso do dizer das palavras que, diante desse fracasso, converte-se em coisa dura, compacta e rabugenta. Um dizer que não diz nada e que ninguém quer ouvir.

Um elefante ferido, sangrando e manquitolante e solitário nas florestas devastadas de Moçambique emite, na descrição de Couto, o sentido literal da terra devastada, ferida, moribunda, sonâmbula. Era um sobrevivente dos traficantes de marfim que, desse modo, alimentavam as guerras. O elefante africano em dor e sofrimento pelas savanas seria a última visão do ser da

${ }^{18}$ COUTO, Mia. Terra sonâmbula. São Paulo: Companhia das Letras, 2007. 
terra. Outrora magnânimo, ecoando em suas passadas lentas toda a história da África resiste, agora moribundo e deambulante à espera da morte, pelo sem fim da terra devastada. Como se fora o último sobrevivente de guerras sucessivas e intermináveis que expulsaram os animais para longe de Angola e Moçambique.

O recurso à literatura - o livro de Kindzu - como narrativa alteritária na travessia pela terra arrasada pelas guerras, indica que quando não houver mais nada, a potência sobrevivente restaria na possibilidade de sonhar o sonho dos outros. Tuahir e seu pai/tio vagando, e sonhando os sonhos que Kindzu escreveu como traço da preservação que ainda jaz na potência de um livro. O livro e a voz seriam os últimos objetos precários e desimportantes capazes de ressemear uma terra vazia das coisas e das palavras. Vazia de delicadezas.

O sonambulismo, como efeito do traumático, prepara e aprofunda os debates contemporâneos sobre o testemunho nos quais, no infinito da linguagem, reage e vive a vocação primeira da imagem que aspira tornar-se narrativa do indizível e, quiçá, devolver aos sonâmbulos seu direito à experiência seminal do sonhar. 